TAPROBANICA, ISSN 1800-427X. August, 2014. Vol. 06, No. 02: pp. 140.

(C) Research Center for Climate Change, University of Indonesia, Depok, Indonesia \& Taprobanica Private Limited, Homagama, Sri Lanka http://www.sljol.info/index.php/tapro

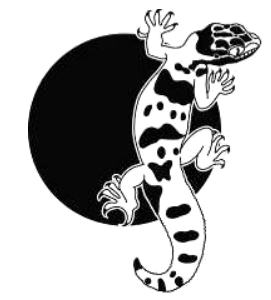

\section{Solanum diphyllum (Solanaceae) in India}

Solanum diphyllum L., commonly known as two-leaf nightshade, is native to Mexico south to Costa Rica in Central America but widely naturalized in many tropical and subtropical regions of the world having escaped from cultivation. The first occurrence of $S$. diphyllum in India was reported in 1995 from two locations in the Howrah District of West Bengal where it was known from only a few individuals (Paul and Biswas, 1995). The species went unnoticed for several years until a large population near Bhushi dam and the Ambavane area of Lonavala town, Pune District, was found by the senior author in 2006. According to local sources the species had been present for seven or eight year and, in 2006 , it was found to have occupied grasslands and forests edges in the towns of Lonavala and Khandala as well as most of the wastelands of Pune, Pimpri-Chinchwad, and other nearby towns. It was also found in various botanical gardens in the city of Pune including the Empress Garden, Mudwa Experimental Garden of Botanical Survey of India (BSI), the associated garden of BSI office campus, and other public gardens. This species is now common in the entire Acharya Jagadish Chandra Bose Indian Botanic Garden, BSI, Howrah, where it is a serious weed. We hereby asked for the immediate mobilization of concerned agencies to adopt measures for control of this fast spreading perennial weed before it becomes a problem for the native flora which in turn may be detrimental for the existence of native, endemic and endangered species, many of which exist in nearby areas of Pune, and more so in Lonavala and Khandala, the microcentres of several narrow endemics. Information about the species, including a detailed description, is available at <http://www.nhm.ac.uk/researchcuration/research /projects/solanaceaesource/taxonomy/descriptiondetail.jsp?spnumber $=2212>$.

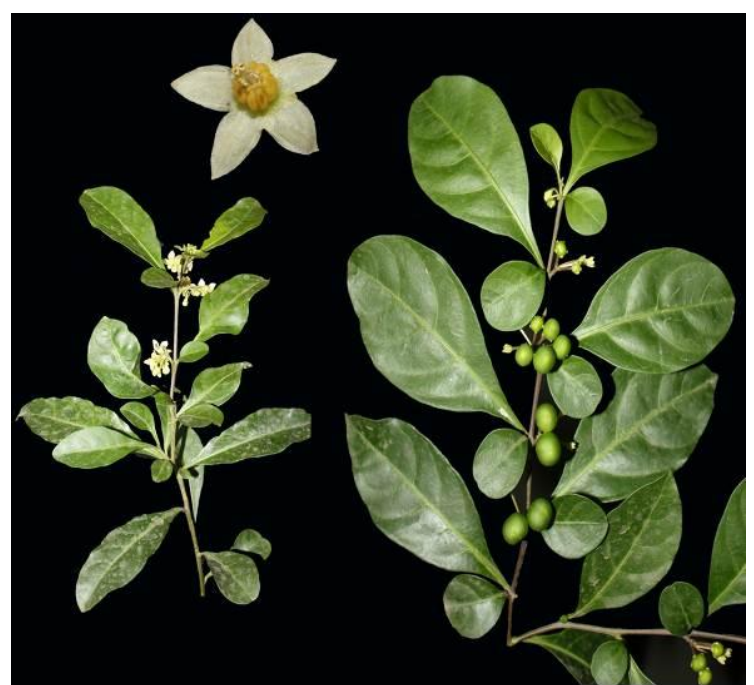

Figure 1: Solanum diphyllum L. in flowering (left) and fruiting (right).

\section{Acknowledgements}

The authors are thankful to the Director (BSI), and the HoO, Central and Western Regional Centres, BSI, for facilities.

\section{Literature cited}

Paul, T. K. and M. C. Biswas, 1995. Solanum diphyllum L., a new record for India, Bulletin of the Botanical Survey of India, 37(1-4): 137138.

Submitted: 11 Feb. 2014, Accepted: 12 May 2014 Section Editor: James L. Reveal

R. Kr. Singh ${ }^{1}$, J. S. Jalal ${ }^{2}$ \& C. R. Jadhav ${ }^{3}$

${ }^{1}$ Botanical Survey of India, Central Regional Centre, 10, Chatham Lines, Allahabad 211002, U. P., India E-mail: rksbsiadsingh@yahoo.co.in

${ }^{2,3}$ Botanical Survey of India, Western Regional Centre, 7, Koregaon Road, Pune 411001, Maharashtra, India 